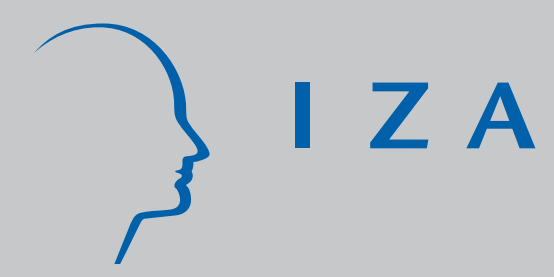

IZA DP No. 3938

Are Young and Old Workers Harmful for Firm Productivity?

Thierry Lallemand

François Rycx

J anuary 2009 


\title{
Are Young and Old Workers Harmful for Firm Productivity?
}

\author{
Thierry Lallemand \\ Université Libre de Bruxelles, DULBEA \\ François Rycx \\ Université Libre de Bruxelles, \\ CEB, DULBEA and IZA
}

Discussion Paper No. 3938

January 2009

\author{
IZA \\ P.O. Box 7240 \\ 53072 Bonn \\ Germany \\ Phone: +49-228-3894-0 \\ Fax: +49-228-3894-180 \\ E-mail: iza@iza.org
}

Any opinions expressed here are those of the author(s) and not those of IZA. Research published in this series may include views on policy, but the institute itself takes no institutional policy positions.

The Institute for the Study of Labor (IZA) in Bonn is a local and virtual international research center and a place of communication between science, politics and business. IZA is an independent nonprofit organization supported by Deutsche Post World Net. The center is associated with the University of Bonn and offers a stimulating research environment through its international network, workshops and conferences, data service, project support, research visits and doctoral program. IZA engages in (i) original and internationally competitive research in all fields of labor economics, (ii) development of policy concepts, and (iii) dissemination of research results and concepts to the interested public.

IZA Discussion Papers often represent preliminary work and are circulated to encourage discussion. Citation of such a paper should account for its provisional character. A revised version may be available directly from the author. 
IZA Discussion Paper No. 3938

January 2009

\begin{abstract}
Are Young and Old Workers Harmful for Firm Productivity?*

This paper investigates the effects of the workforce age structure on the productivity of large Belgian firms. More precisely, it examines different scenarios of changes in the proportion of young (16-29 years), middle-aged (30-49 years) and old (more than 49 years) workers and their expected effects on firm productivity. Using detailed matched employer-employee data, we find that a higher share of young (old) workers within firms is favourable (harmful) for firm value added per capita. Results also show that age structure effects on productivity are stronger in ICT than in non-ICT firms.
\end{abstract}

JEL Classification: J21, J31, L25

Keywords: firm performance, workforce age structure, demographic changes

Corresponding author:

François Rycx

Université Libre de Bruxelles

CP 140, Av. F.D. Roosevelt 50

B-1050 Brussels

Belgium

E-mail: frycx@ulb.ac.be

\footnotetext{
This paper is produced as part of a research contract for the European Commission (DG Employment, No. VT/2005/92) entitled "Study and Conference on European Labour Market Analysis using Firm-Level Panel Data and Linked Employer-Employee Data" (http://cep.Ise.ac.uk/leed/). Financial support from the National Bank of Belgium is gratefully acknowledged. We also would like to thank Statistics Belgium for giving access to the Structure of Earnings Survey and the Structure of Business Survey. The usual disclaimer applies.
} 


\section{INTRODUCTION}

There is strong evidence that the average age of the population is steadily increasing in most European countries. This ongoing demographic change might have serious consequences for the management of human resources within firms. This paper aims to examine one of these effects. More precisely, we want to investigate whether the age structure of the workforce has an impact on the productivity of Belgian firms. This issue is of major importance for economic policy as most production in Belgium draws on prime-aged workers (25-54 age group). Indeed, Belgium's employment rate for people aged 55-64 is one of the lowest in the OECD area (34\% in 2007 (OECD, 2008)). The withdrawal of older people from the Belgian labour market is mainly due to the existence of attractive (to both employers and employees) early retirement schemes. It also derives from the fact that older workers are often considered by employers as more costly and less productive than prime-aged workers. Moreover, Belgium is characterized by a low employment rate and a high unemployment rate (19\% in 2007 (OECD, 2008)) for people aged 15-24. Most young unemployed have a low level of education (OECD, 2007). This is not surprising as firms often complain that young workers have a lack of relevant skills and therefore prefer to opt for middle-aged individuals. Finally, let us notice that the rapid ageing process of the population requires policy-makers in most European countries, and certainly in Belgium, to find solutions to reduce the pressure that the demographic dependency ratios put on public finances. One way to deal with this issue is to increase the employment rate of people aged 55-64 (the European target stands at 50\% for 2010). Another (complementary) solution would be to improve the employment prospects of young people. These changes in the workforce age structure may have important consequences for the productivity of firms. Yet, the empirical evidence on this issue is surprisingly limited. Moreover, as far as we know, this question has never been investigated for Belgium. 
The theoretical literature on the relation between age and productivity is ambiguous. On the one hand, several theories suggest that older workers are more productive. Mincer (1974), for instance, argues that older workers have more job experience and know-how, which increases their individual performance. There is also a higher probability that they have been assigned to their best position in the firm organization (Jovanovic, 1979). Moreover, they are more likely to have correctly matched their job preferences with the employer's requirements (Johnson, 1978). Autor et al. (2003) expect a rise of the performance of older workers over time. The point is that during the last decade the demand for interactive skills on the US labour market (i.e. abilities which do not generally vary with age) has increased more than the demand for problem-solving and mathematical abilities (i.e. skills that are supposed to be declining with age). On the other hand, there are multiple factors suggesting that younger workers are more productive. One of the most frequently cited arguments is that a worker's health tends to deteriorate over the life cycle (e.g. diseases, absenteeism, body strength, depression, etc.). In addition, it is argued that cognitive abilities generally decrease with age. ${ }^{1}$ This may result in a lower productivity level of older workers, unless their job experience and specific knowledge compensate for their inferior cognitive skills. ${ }^{2}$ Besides, young people are thought to be more motivated to exert higher effort since they want to give a good signal to their employer (Grund and Westergaard-Nielsen, 2005). In contrast, older people might be less willing to invest in training programmes since they are closer to retirement and cannot learn new skills well (Hayward et al., 1997). This is in general the perception that employers have of older workers (Itzin et al., 1994). Moreover, employers might be more reluctant to invest in training for older workers because they have a shorter period of time to benefit from on-the-job training (Brooke, 2003; Prskawetz et al., 2006).

\footnotetext{
${ }^{1}$ Cognitive abilities reflect inter alia numerical capabilities and verbal, reasoning and problem solving abilities.

${ }^{2}$ See Skirbekk (2003) for a broad literature review on this issue.
} 
Nevertheless, the reverse argument might also hold since young workers change jobs more often, which might reduce the return of employers to on-the-job training (Taylor and Urwin, 2001).

The empirical literature regarding the impact of the workforce age structure on the productivity of firms is still limited. Most papers, relying on matched employer-employee data, report a positive and hump-shaped relationship between workforce age and firm performance. In general, strong decreases in productivity are observed after the age of $50 .^{3}$ However, two studies found that productivity peaks at 55 years or more (Hellerstein and Neumark, 1995; Hellerstein et al., 1999). Yet, these results may be attributed to the poor quality of data in the former study and to the use of output as an estimate of productivity in the latter. In general, studies investigating the age-productivity relationship use workers' mean age or shares of workers by age groups as an indicator of the age structure of the workforce, while the most common measure of firm productivity is firm's value added. Yet, many papers rely on cross-sectional data and/or focus on a particular sector of economic activity (in general, the manufacturing and mining sector).

This paper is the first to investigate the effects of the workforce age structure on firm productivity in the Belgian private sector. Our main objective is to show whether shifts in the current workforce age structure would be beneficial or detrimental for the productivity of Belgian firms. More precisely, we examine different scenarios of changes in the proportion of young and old workers and their effects on firm productivity. This paper contributes significantly to the existing literature as it is one of few to: i) focus on more than one or two industries, ii) show the impact on productivity of all possible changes in the proportion of

\footnotetext{
${ }^{3}$ See Andersson et al. (2002) for Sweden, Aubert and Crépon (2003) for France, Dostie (2006) for Canada, Grund and Westergaard-Nielsen (2005) for Denmark, Haegeland and Klette (1999) for Norway, Haltiwanger et al. (1999) for US, Hellerstein and Neumark (2004) for US, Malmberg et al. (2005) for Sweden, Prskawetz et al. (2006) for Austria.
} 
young, prime-aged and old workers at the firm level, iii) distinguish between ICT and nonICT firms, and iv) deal with the potential endogeneity problem of the workforce age structure. $^{4}$

In the first part of the paper, we use two detailed matched employer-employee data sets for the years 1995 and 2003. It enables us to test the stability of the results over time and to take into account (to a certain extent) the potential cohort effects that could drive age effects. Our data sets derive from the combination of the Structure of Business Survey (SBS) and the Structure of Earnings Survey (SES). The former provides firm-level information on financial variables and in particular on the productivity of the workforce (e.g. value added). The latter contains detailed information on individual workers (e.g. gross hourly wages, age, education, sex, and occupation) and on firm characteristics (e.g. sector of activity, level of wage bargaining, and firm size).

In the second part of the paper, we perform sensitivity and robustness tests. First, we examine whether results may differ across firms that use ICT intensively and those that do not. Next, we address two potential problems linked to the robustness of OLS estimates of age effects. To do so, we rely on a unique small panel data set of firms built from a combination of the SES and SBS in 1995 and 2003. On the one hand, we try to correct for the endogeneity of workforce age structure using its lagged values. On the other hand, we try to control for firm fixed effects by estimating our model in first differences.

The plan of the rest of the paper is as follows. We first present the data set in section II and describe our methodology in the next section. In section IV, we explain our sampling

\footnotetext{
${ }^{4}$ Recently, several papers have tried to overcome this problem. For papers using IV estimations to correct for the bias of simultaneity, see: Andersson et al. (2002), Aubert and Crépon (2003) and Malmberg et al. (2005). In contrast, Hellerstein and Neumark (2004) and Dostie (2006) follow the methodology developed by Olley and Pakes (1996) and Levinshon and Petrin (2003), which consists in proxying firm's unobservable productivity shocks by either investments or intermediate inputs.
} 
scheme and show several descriptive statistics. Section V is devoted to the presentation and discussion of the main results. In sections VI and VII, we run sensitivity and robustness tests. We draw some conclusions in the last section.

\section{DATA SET}

Each final data set (for 1995 and 2003) is based upon a unique combination of two large-scale data sets. The first, conducted by Statistics Belgium ${ }^{5}$, is the Structure of Earnings Survey (SES). It covers all Belgian firms employing at least 10 workers and with economic activities within sections $\mathrm{C}$ to $\mathrm{K}$ of the NACE Rev.1 nomenclature. It thus encompasses the following sectors: mining and quarrying (C), manufacturing (D), electricity and water supply (E), construction (F), wholesale and retail trade, repair of motor vehicles, motorcycles and personal and household goods $(\mathrm{G})$, hotels and restaurants $(\mathrm{H})$, transport, storage and communication (I), financial intermediation (J), and real estate, renting and business activities (K). The survey contains a wealth of information, provided by the management of the firms, both on the characteristics of the firms (e.g. sector of activity, number of workers, level of collective wage bargaining, type of economic and financial control, region) and on the individual employees (e.g. age, educational level, tenure, gross earnings, paid hours, sex, occupation, type of contract).

The SES provides no financial information. This is why the SES has been combined with the Structure of Business Survey (SBS). It is a firm-level survey, conducted by Statistics Belgium, with a different coverage than the SES in that it includes neither the financial sector

\footnotetext{
${ }^{5}$ According to the instructions given by Eurostat (E-U regulation Nr. 2744/95).
} 
$\left(\right.$ NACE J) ${ }^{6}$ nor firms with less than 20 employees. Both data sets have been merged by Statistics Belgium using firms' social security number. The SBS provides firm-level information on financial variables such as sales, value added, value of production and gross operating surplus.

\section{METHODOLOGY}

In order to investigate the effects of the workforce age structure on firm productivity, we estimate a regression where the dependent variable is the productivity per worker. The age structure of the workforce within a plant is measured by several age shares variables (3 categories). In addition, we control for a large list of variables influencing firm performance.

$$
\ln P_{j}=\alpha+\beta_{1} \ln A_{1 j}+\beta_{2} \ln A_{2 j}+\beta_{3} \ln A_{3 j}+\gamma X_{j}+\delta Y_{j}+\varepsilon_{j}
$$

$P_{j}$ is the productivity of firm $j$ and is measured by the value added per employee. The value added (at factor costs) per employee is obtained by dividing the firm's annual gross operating income (plus subsidies, minus indirect taxes) by the number of workers in the firm. We split employees of a firm into three age groups: $<30,30-49$, 50+. Afterwards we calculate the share of workers in each of these three categories that we integrate as explanatory variables in the regression $\left(A_{1 j}, A_{2 j}, A_{3 j}\right)$. We believe that these age groups provide a good representation of the different stages in the individual life cycle. Indeed, as noted by Malmberg et al. (2005), one may suppose that workers younger than 30 years are more healthy, mobile and motivated individuals. The middle-aged workers might i) have heavier family responsibilities, ii) be

\footnotetext{
${ }^{6}$ In 2003, the SBS includes a small fraction of the financial sector, i.e. NACE 652 (Other financial intermediation) and 67 (Activities auxiliary to financial intermediation).
} 
more experienced and iii) hold important management responsibilities. Workers older than 50 years of age could i) have a good knowledge of themselves (e.g. they know how to be productive with a minimum of effort), ii) have a better matching of their abilities with their job preferences, iii) be less motivated to learn and iv) suffer a weakening of their health. Moreover, using the log of age groups allows to include all three categories in spite off the fact that non-logged values sum up to $1 . X_{j}$ is a set of aggregate worker characteristics per firm. It comprises: the mean and standard deviation of education (number of years of schooling $)^{7}$, the mean and standard deviation of gross hourly wages ${ }^{8}$, the share of blue-collar workers, the share of women, and the percentage of part-time workers. $Y_{j}$ is a set of firm characteristics : the size (exact number of employees), the industrial sector (at the NACE one digit level), the level of collective wage agreement, the regional affiliation, and the type of economic and financial control.

\section{SAMPLING AND DESCRIPTIVE STATISTICS}

Since sampling percentages of employees in the 1995 and 2003 SES depend on firm size, we decide to focus on firms employing at least 100 individuals in order to have a sufficient

\footnotetext{
${ }^{7}$ The idea is to take into account the fact that firms with a higher mean level of skilled workers may perform better. Moreover, as shown in the literature (see Iranzo et al. (2008) for a broadly detailed review), skill dispersion and firm productivity may also be linked.

${ }^{8}$ We include the mean value of gross hourly wages within each firm in order to control for efficiency wage effects (see Akerlof and Yellen (1986) and Weiss (1991)). Moreover, we account for the dispersion of earnings within firms because of the (dis)incentive effect of wage inequality within firms on firm performance (see Lallemand et al. (2004, 2007) for empirical evidence)).
} 
number of observations per firm. ${ }^{9}$ This selection criterion leads to an average number of observations per firm that is equal to 32 in 1995 and 26 in 2003. Using this criterion, there remains a low percentage of firms with less than 10 observations (5.3\% in 1995 and $0.2 \%$ in 2003). To maximize the quality of age shares variables, we prefer to drop these firms. We also restrict the analysis to firms with a positive value added. Indeed, the idea is to avoid that estimates of age structure effects are biased by firms with a negative value added since the latter are more likely to close down. Actually, only 2 firms in 1995 and 7 firms in 2003 have a negative productivity. The two final samples cover 691 firms in 1995 and 1,204 firms in 2003.

\section{[Insert Table 1]}

Table 1 sets out the means (standard deviations) of selected variables. Descriptive statistics are quite stable over time. Firms have a mean value added per capita of around 70,000 euros in 2003. In 1995, the age structure of the workforce within firms is on average composed by: 26 percent of workers younger than 30 years, 60 percent of prime aged workers (between 30 and 49 years) and 14 percent of older workers (with at least 50 years). In 2003, these figures are very similar. However, one may notice a slight increase in the share of older

\footnotetext{
${ }^{9}$ The SES is a stratified sample. The stratification criteria refer respectively to the region (NUTS1), the principal economic activity (NACE-groups) and the size of the firm (determined by the data obtained from the Social Security Organisation). The sample size in each stratum depends on the size of the firm. Sampling percentages of firms equal respectively 10,50 and $100 \%$ when the number of workers is lower than 50 , between 50 and 99 , and above 100. Within a firm, sampling percentages of employees also depend on size. Sampling percentages of employees reach respectively 100, 20 and 10\% when the number of workers is lower than 50, between 50 and 99, and above 100. The consequence of these stratification criteria is that the number of data points depends upon firm size.
} 
workers and a 4 percentage points decrease in the proportion of younger workers. Firms are composed on average of workers who are 37 years old and the standard deviation of workers' age is slightly above 9 years. Other workforce characteristics do not vary very much between 1995 and 2003. In 1995, i) the share of women within firms amounts approximately to $28 \%$, ii) the average number of years of tenure reaches 11 years, iii) the mean number of years of schooling is equal to 11 , and iv) the share of blue collar workers amounts to $46 \%$. In both samples, the three most representative sectors of economic activity are: i) manufacturing (around 50\%), ii) wholesale and retail trade firms (around 20\%) and iii) real estate, renting and business activities (around 15\%). In 1995, we have data on electricity and water supply (NACE E, around 1\%) but we do not observe any firms within financial activities (NACE J). The reverse pattern holds for 2003. Also noteworthy is that most of Belgium's economic activity is concentrated in Flanders, whatever the year of reference. Finally, descriptive statistics indicate that around $40 \%$ of firms renegotiate national and/or sectoral collective wage agreements at the local level. ${ }^{10}$

\footnotetext{
${ }^{10}$ In Belgium, as in the majority of European countries, wage bargaining occurs at multiple levels: the national (inter-professional) level, the sectoral level and the company level. They generally occur every two years on a pyramidal basis. In principle, they are inaugurated by a national collective agreement defining a minimum level in wage terms. This national agreement can be improved within every sector of activity. Then we have the company negotiations where the sectoral collective agreements may be renegotiated (except where there is an imperative clause). However, these cannot give rise to a collective agreement which would run counter to the sectoral and/or national agreements. In other words, the wage bargained at the firm level can only be greater or equal to the wage set at the national and/or industry level (except in particular cases where there is an opt-out clause).
} 


\section{GENERAL ANALYSIS}

Table 2 contains the estimates of age shares effects on firm productivity in 1995 and 2003. Regressions, based on equation (1), have been estimated by OLS with White (1980) heteroscedasticity-consistent standard errors. Control variables (respectively, workforce and firm characteristics) have been included step by step in order to examine how the age effects on firm productivity change.

\section{[Insert Table 2]}

Columns (1) and (4) present the results when firm productivity is explained by the age structure of the workforce solely. In 1995, each age variable has a positive effect on firm productivity but the coefficient associated with middle-aged workers is the only one to be significant. In 2003, all age coefficients are positive and significant, except the variable of young workers which is not significant. Consecutively to the inclusion of firm-level characteristics of the workforce (education, gender, occupation) and information on compensation schemes (wage and working time) the coefficient associated with the share of younger workers becomes significant (see columns (2) and (4)). Adding industry dummies and other firm characteristics reduces the value of each coefficient (see columns (3) and (6)). Also noteworthy is that the share of older workers remains not significant in 1995 . The $\mathrm{R}^{2}$ of the model is around 68\% in 1995 and 50\% in 2003.

[Insert Table 3] 
Interpretation of results from Table 2 is not so straightforward. Indeed, the age shares variables cannot vary independently of each other. In other words, a decrease in the value of one variable must be accompanied by a corresponding increase in one or two of the other age categories. Moreover, the overall effect of increasing or decreasing the share of workers in a given age category depends on the initial size of each age group. From Table 1, it appears that a typical firm is composed in 2003 of around 22\% of young people ( $<30$ years), $61 \%$ of middle-aged workers (30-49 years) and 17\% of elderly individuals (at least 50 years). The overall effects on firm productivity of increasing the share of one age group while decreasing one of the two other categories are presented in Table 3. Let us take an example. In 2003, a 10 percent increase in the proportion of young workers to $24.2 \%$ combined with a corresponding decrease of middle-aged workers to $58.8 \%$ (i.e. a 2.2 percentage points decrease representing a reduction of 3.6 percent of middle-aged workers with respect to the initial share) should increase firm productivity by around 0.6 percent on average (i.e. $\left.\left(10^{*} 0.137\right)-(3.6 * 0.205)\right)$. A very similar result is found if a rise in the share of young workers is combined with a decrease in the proportion of older individuals. Two other interesting results appear from Table 3. On the one hand, replacing young individuals with middle-aged workers reduces the productivity of firms. On the other hand, raising the concentration of older workers decreases firm productivity, regardless whether older individuals replace young or middle-aged workers. However, this negative effect is lower when firms employ older individuals instead of middleaged workers. To some extent, our results are quite in line with what one could expect from previous findings in the literature. ${ }^{11}$ Indeed, our findings indicate that large Belgian firms (with a minimum of 100 workers) might increase their value added by i) raising the share of younger people or ii) increasing the proportion of middle-aged workers and simultaneously

\footnotetext{
${ }^{11}$ See Aubert and Crépon (2003), Dostie (2006), Grund and Westergaard-Nielsen (2005), Haegeland and Klette (1999), Haltiwanger et al. (1999), Hellerstein and Neumark (2004), Ilmakunnas and Maliranta (2005).
} 
lowering the share of older workers. In contrast, firm productivity is negatively affected by an increase in the share of older workers. In other words, older workers seem to be harmful for firm productivity. Even if our results are qualitatively the same across the two time periods, the magnitude of the effects of changing the workforce age structure is stronger in 1995 . In other words, a higher proportion of old workers (young and middle-aged workers) is found to be more detrimental (favourable) for firm productivity in 1995 than in 2003. How can we explain that age effects are weaker in 2003? First, it might be due to the sample size which is bigger in 2003. Hence, information on the composition of workforce age is more precise. Second, labour market indicators are better (the employment rate is higher and the unemployment rate lower for each age category) and on-the-job training is more systematically integrated within firms. In addition, continuous training is less unequally distributed across individuals (SPF Economie, 2005).

\section{SENSITIVITY ANALYSIS}

Firms do not use the same technologies and their economic activities do not require the same amount of investment in innovation. This implies that firms may need different types of worker skills. Indeed one may expect that firms using new advanced technologies will employ individuals with strong cognitive skills and learning capabilities. Since such abilities are decreasing over the worker's life cycle and innovative firms are also more likely to invest in on-the-job training programmes, it could be more profitable for innovative firms to employ a higher share of younger workers. Unfortunately, our data set does not comprise information on technological and innovative activities of firms. Therefore, we rely on an ICT taxonomy developed by O’Mahoney and van Ark (2003), which distinguishes firms according to the ICT capital intensity of industrial sectors at the NACE three digit level. This methodology 
groups industries based on whether they produce ICT goods and services and whether they intensively use ICT or not.

\section{[Insert Table 4]}

Differences in age profiles between firms using and producing ICT intensively on the one hand ${ }^{12}$ and firms relying less intensively on ICT on the other ${ }^{13}$ are not very large. However, Table 4 indicates that ICT sectors employ more young workers while non-ICT

${ }^{12}$ ICT firms are found in the following sectors: Clothing (NACE 18); Printing and publishing (NACE 22); Mechanical engineering (NACE 29); Other electrical machinery and apparatus, except insulated wire (NACE 31); Other instruments, except scientific instruments (NACE 33); Building and repairing of ships and boats (NACE 351); Aircraft and spacecraft (NACE 353); Furniture, miscellaneous manufacturing; recycling (NACE 36-37); Wholesale trade and commission trade, except of motor vehicles and motorcycles (NACE 51); Retail trade, except of motor vehicles and motorcycles; repair of personal and household goods (NACE 52); Financial activities, except insurance and pension funding (NACE 65); Activities auxiliary to financial intermediation (NACE 67); Renting of machinery and equipment (NACE 71); Legal, technical and advertising (NACE 741-3); Office machinery (NACE 30); Insulated wire (NACE 313); Electronic valves and tubes (NACE 321); Telecommunication equipment (NACE 322); Radio and television receivers (NACE 323); Scientific instruments (NACE 331); Communications (NACE 64); Computer and related activities (NACE 72).

${ }^{13}$ Non-ICT firms are found in the following sectors: Quarrying (NACE 14); Food, drink and tobacco (NACE 1516); Textiles (NACE 17); Leather and footwear (NACE 19); Wood and products of of wood and cork (NACE 20); Pulp, paper and paper products (NACE 21); Mineral oil refining, coke and nuclear fuel (NACE 23); Chemicals (NACE 24); Rubbers and plastics (NACE 25); Non-metallic mineral products (NACE 26); Basic metals (NACE 27); Fabricated metal products (NACE 28); Motor vehicles (NACE 34); Construction (NACE 45); Sale, maintenance and repair of motor vehicles and motorcycles ; retail sale of automotive fuel (NACE 50); Hotels and restaurants (NACE 55) ; Inland transport (NACE 60); Water transport (NACE 61) ; Air transport (NACE 62) ; Supporting and auxiliary transport activities ; activities of travel agencies (NACE 63) ; Real estate activities (NACE 70) ; Other business activities (NACE 749). 
firms use a slightly larger proportion of middle-aged and old workers. There are other workforce and firm characteristics which differ more severely across ICT and non-ICT firms. On average, ICT firms employ a larger share of women and white-collar workers. Workers within ICT firms are also more educated. Moreover, it is noteworthy that non-ICT firms are most representative of the manufacturing sector (around 70\%) while most ICT firms are in wholesale and retail trade (around 38\%) and real estate, renting and business activities (around 31\%). Figures are qualitatively similar for 1995 and 2003.

[Insert Tables 5 and 6]

Columns (1) and (3) of Table 5 show that each age share variable has a positive and significant impact on firm productivity except the coefficient of older workers in the ICT sectors which is not significant (and negative in 1995). Table 6 indicates that, as expected from earlier results (see section 5), an increase in the share of younger workers has strictly positive effects on ICT and non-ICT firms. On the other hand, a more elderly workforce tends to reduce firm performance. Nevertheless, the magnitude of these effects differs across ICT and non-ICT firms. Indeed, non-ICT firms are less negatively (positively) affected by an increase in the share of older (younger) workers. Moreover, in 2003 the penalty of employing older workers instead of middle-aged workers tends to disappear. Several elements may be put forward to explain such differences in age effects between ICT and non-ICT firms. On the one hand, one may expect that the current technological progress in the ICT sectors requires workers with strong learning abilities and who are able to adjust quickly to new forms of work organization. ICT firms may also prefer people who can perform simple and routine tasks which do not call for much experience but rather for speed and flexibility. Since older workers learn at a slower pace due to age-related declines in processing speed (Baltes and 
Lindenberger, 1997; Hoyer and Lincourt, 1998) and may be less interested in performing such tasks, ICT firms are better off with a higher share of younger workers. On the other hand, firms using ICT intensively need individuals with high current and future cognitive skills. This is why those firms may be more likely to invest in training programmes addressed to younger workers. Indeed, firms may be more reluctant to invest in the training of older workers since i) the period of time left to benefit from such an investment is shorter (Brooke, 2003; Prskawetz et al., 2006), ii) older workers show serious problems in learning something really new (Hayward et al., 1997) and iii) older workers are less motivated to spend time in training systems. Finally, non-ICT firms may suffer less from an older workforce since within these firms job experience and the specific knowledge of elderly workers may compensate for the decrease in other cognitive skills (Skirbekk, 2003).

\section{ROBUSTNESS TESTS}

In this section we address the potential endogeneity problem of workforce age structure, which could bias OLS estimates of age effects. The point is that any unobserved productivity shock might generate correlated changes in the workforce age structure and labour productivity that are not due to the ageing of the workforce per se. For example, one might expect that a firm undergoing a negative productivity shock would prefer not to hire new individuals, which would increase the age of the workforce. Hence, the correlation that we could find, using OLS estimations, between a decrease of firm productivity and the rise of the share of older workers could be purely spurious.

To control for that problem, we build a panel of firms from the SES and SBS for the years 1995 and 2003. Indeed, Statistics Belgium provides us with an additional data set (call it, UNIQUE). This data set comprises information on employer and employee characteristics 
in 2003 coupled with data on value added of firms in 1995. In order to have a panel of firms with data on value added in 1995 and 2003 combined with data on workers and firms characteristics for the same years, we merge UNIQUE with the 1995 SES-SBS data set. To do so, we use the 1995 value added per firm since the identification codes of firms (randomized numbers) differ across these two data sets. We keep firms with a minimum of 100 workers and drop those with: i) the same value added (to avoid wrong combinations of firms) and ii) at least one age share equal to zero (because the logarithm of zero does not exist). Our final sample, containing 161 firms, is representative of the whole Belgian private sector with the exception of: i) mining and quarrying, ii) electricity, water and gas supply, and iii) financial activities. Also noteworthy is that workforce characteristics, and more particularly the age categories, are calculated on an average number of observations equal to $25 .^{14}$

To correct for the risk of an endogeneity bias in OLS estimates of age effects, we replace each age variable in 2003 by its lagged value in 1995. In other words, we regress the value added (per capita) per firm in 2003 on these three lagged variables and we control for many other workforce and firm characteristics in $2003 .^{15}$

[Insert Tables 7 and 8]

\footnotetext{
${ }^{14}$ See Appendix I for the descriptive statistics of the panel.

${ }^{15}$ We could also instrument age share variables in 2003 with their respective values in 1995 . However, doing so does not add very much to what we did since we can not test the validity of our instrument. Indeed, because we have only one instrument for one variable to be instrumented, we cannot run the Sargan's (1964) overidentification test. Another way to control for the simultaneity problem is to use the semi-parametric estimators developed either by Olley and Pakes (1996) or Levinsohn and Petrin (2003). Nevertheless, we cannot rely on these alternative approaches since we do not have data on firm investments and intermediate inputs.
} 
The most important difference with previous results (when we do not address the endogeneity problem) is that age effects are bigger. A higher share of younger workers increases firm productivity while employing a larger proportion of older workers (this effect was not very large in 2003) generates stronger detrimental effects (Table 8). To put it differently, these results highlight the benefits of hiring young and middle-aged workers. ${ }^{16}$ On the other hand, raising the concentration of older workers leads to productivity losses.

\section{CONCLUSION}

We investigated the impact of the workforce age structure on the productivity of large Belgian firms. More precisely, we examined different scenarios of changes in the proportion of young (16-29 years), middle-aged (30-49 years) and old (more than 49 years) workers and their expected effects on firm productivity. Our paper contributes significantly to the existing literature as it is one of few to: i) focus on more than one or two industries, ii) show the impact on productivity of all possible changes in the proportion of young, prime-aged and old workers at the firm level, iii) distinguish between ICT and non-ICT firms, and iv) deal with

\footnotetext{
${ }^{16}$ Another problem is that firm productivity might be influenced by fixed and quasi-fixed characteristics of firms (overall in industrial plants). The idea is that the production characteristics of a firm, inter alia the workforce composition within a firm, might be reflective of the technology adopted at the time of the creation of that firm. Hence, one can be wrong in attributing the effects of age variables on firm productivity to an ageing of the workforce instead of technological age of the firm. To analyse whether age effects obtained with OLS are driven by firm fixed effects, we regress the difference in the log of valued added between 2003 and 1995 on the difference in the age share variables, controlling for the difference in the other variables of our model. However we do not find any statistically significant relationship between these variables. One reason might be the relatively small size of our sample. Another might be that the lag between 1995 and 2003 is too big, so that it is difficult to isolate the existence of a relationship between the variation in firm productivity and changes in workforce age structure.
} 
the potential endogeneity problem of the workforce age structure. Moreover, it is the first to analyse the effects of changes in the workforce age structure on the productivity of firms in the Belgian private sector.

Empirical findings, based on two cross-sectional employer-employee matched data sets for 1995 and 2003, show that a higher share of young workers within firms is favourable for productivity. In contrast, an older workforce age structure is found to be harmful for firm value added per capita. These findings are robust to the potential simultaneity problem between firm productivity and workforce age structure. We addressed this issue using a unique panel data set. Finally, additional results indicate that an increase in the share of young (old) workers has a stronger positive (negative) effect on the productivity of ICT firms than non-ICT firms.

A better understanding of the influence of fixed unobserved characteristics of firms on productivity is surely a very promising question for future research. Furthermore, it would be interesting to examine whether age effects on productivity vary according to firm size. Yet, at the moment these issues cannot be investigated for the Belgian economy because of data limitations.

\section{REFERENCES}

Akerlof, G. A. and J. L. Yellen (1986), Efficiency Wage Models of the Labor Market, Cambridge, Cambridge University Press.

Andersson, B., B. Holmlund, and T. Lindh (2002), Labor Productivity, Age and Education in Swedish Mining and Manufacturing 1985-96, unpublished paper, Uppsala University, Sweden. 
Aubert, P. and B. Crépon (2003), 'La productivité des salariés âgés: une tentative d'estimation,' Economie et Statistique, 368, pp. 95-119.

Autor, D. H., F. Levy, and R. J. Murnane (2003), 'The Skill Content of Recent Technological Change: An Empirical Exploration,' Quarterly Journal of Economics, 118, pp. 12791333.

Baltes, P. B. and U. Lindenberger (1997), 'Emergence of a Powerful Connection between Sensory and Cognitive Functions across the Adult Life Span. A New Window to the Study of Cognitive Aging?,' Psychology and Aging, 12, pp. 12-21.

Brooke, L. (2003), Human Resources Costs and Benefits of Maintaining a Mature-age Workforce,' International Journal of Manpower, 24, pp. 260-284.

Dostie, B. (2006), Wages, Productivity and Aging, IZA discussion paper nr. 2496, Bonn.

Grund, C. and N. Westergaard-Nielsen (2005), Age Structure of the Workforce and Firm Performance, IZA discussion paper nr. 1818, Bonn.

Haegeland, T. and T. J. Klette (1999), 'Do Higher Wages Reflect Higher Productivity? Education, Gender and Experience Premiums in a Matched Plant-worker Data Set,' in: J. C. Haltiwanger, J. I. Lane, J. R. Spletzer, J. Theeuwes, and K. R. Troske (eds.), The Creation and Analysis of Employer-employee Matched Data, Elsevier Science, NorthHolland, pp. 231-59.

Haltiwanger, J. C., J. L. Lane, and J. R. Spletzer (1999), Productivity Differences Across Employers. The Roles of Employer Size, Age and Human Capital,' American Economic Review, 89, pp. 94-8.

Hayward, B., S. Taylor, N. Smith and, C. Davies (1997), Evaluation of the Campaign for Older Workers, HMSO, Norwich. 
Hellerstein, J. K. and D. Neumark (1995), ‘Are Earnings Profiles Steeper than Productivity Profiles? Evidence from Israeli Firm Data,' Journal of Human Resources, 30, pp. 89112.

Hellerstein, J. K., D. Neumark, and K. R. Troske (1999), 'Wages, Productivity and Worker Characteristics: Evidence from Plant-level Production Functions and Wage Equations,' Journal of Labor Economics, 17, pp. 409-46.

Hellerstein, J. K. and D. Neumark (2004), Production Function and Wage Equation Estimation with Heterogeneous Labor: Evidence from a New Matched Employeremployee Data Set, NBER working paper nr. 10365, Cambridge, MA.

Hoyer, W. J. and A. E. Lincourt (1998), ‘Aging and the Development of Learning,’ in: P. A. Frensch and M. A. Stadler (eds.), Handbook of Implicit Learning, Sage Publications, pp. 445-70.

Ilmakunnas, P. and M. Maliranta (2005), 'Technology, Labour Characteristics and WageProductivity Gaps,' Oxford Bulletin of Economics and Statistics, 67, pp. 623-44.

Iranzo, S., S. Fabiano, and E. Tosetti (2008), 'Skill Dispersion and Firm Productivity: An Analysis with Employer-employee Matched Data,' Journal of Labor Economics, 26, pp. 247-85.

Itzin, C., C. Phillipson, and F. Laczko (1994), 'Age Barriers at Work - Maximizing the Potential of Mature and Older Workers [Review],' Journal of Social Policy, 23, pp. 119. Johnson, W. R. (1978), A Theory of Job Shopping,' Quarterly Journal of Economics, 92, pp. 261-77.

Jovanovic, B. (1979), 'Job Matching and the Theory of Turnover,' Journal of Political Economy, 87, pp. 972-90.

Lallemand, T., R. Plasman, and F. Rycx (2004), 'Intra-firm Wage Dispersion and Firm Performance: Evidence from Linked Employer-employee Data,’ Kyklos, 57, pp. 541-66. 
Lallemand, T., R. Plasman, and F. Rycx (2007), Wage Structure and Firm Productivity in Belgium, NBER working paper nr. 12978, Cambridge, MA.

Levinshon, J. and A. Petrin (2003), 'Estimating Production Functions Using Inputs to Control for Unobservables,' Review of Economic Studies, 70, pp. 317-42.

Malmberg, B., T. Lindh, and M. Halvarsson (2005), Productivity Consequences of Workforce Ageing - Stagnation or Horndal Effect ?, Working paper nr. 2005-17, Institute for Futures Studies, Stockholm.

Mincer, J. (1974), Schooling, Experience and Earnings, New-York, NBER Press.

OECD (2007), Jobs for Youth : Belgium, OECD, Paris.

OECD (2008), Employment Outlook, OECD, Paris.

Olley, S. G. and A. Pakes (1996), 'The Dynamics of Productivity in the Telecommunications Equipment Industry,’ Econometrica, 64, pp. 1263-97.

O’Mahoney, M. and B. van Ark (2003), EU Productivity and Competitiveness: An Industry Perspective - Can Europe Resume the Catching-up Process ?, European Commission, Luxembourg.

Prskawetz, A., B. Mahlberg, V. Skirbekk, I. Freund, M. Winkler-Dworak, T. Lindh, B. Malmberg, O. S. Nordström, and Andersson F. (2006), The Impact of Population Ageing on Innovation and Productivity Growth in Europe, Research report nr. 28 for the European Commission, Employment, Social Affairs and Equal Opportunities DG, Vienna Institute of Demography.

Sargan, J. D. (1964), 'Wages and Prices in the United Kingdom: A Study in Econometric Methodology,' in: P. E. Hart, G. Mills, and J. K. Whitaker (eds.), Econometric Analysis for National Economic Planning, London, Butterworths.

Skirbekk, V. (2003), Age and Individual Productivity: A Literature Survey, Technical report nr. 2003-028, Max Planck Institute for Demographic Research. 
SPF Economie (2007), Effort des enterprises belges en matière de formation. Résultats de l'enquête CVTS 2005, Report, DGSIE (Statistics Belgium), Brussels.

Taylor, P. and P. Urwin (2004), 'Age and Participation in Vocational Education and Training,' Work Employment and Society, 15, pp. 763-79.

Weiss, A. (1991), Efficiency Wage Models of Unemployment, Layoffs, and Wage Dispersion, Oxford, Clarendon Press.

White, H. (1980), ‘A Heteroscedasticity-consistent Covariance Matrix Estimator and a Direct Test for Heteroscedasticity,' Econometrica, 48, pp. 817-30. 
Table 1: Means and Standard Deviations of Selected Variables ${ }^{+}$

\begin{tabular}{|c|c|c|c|c|}
\hline \multirow{2}{*}{$\begin{array}{l}\text { Year } \\
\text { Variables } \\
\end{array}$} & \multicolumn{2}{|c|}{1995} & \multicolumn{2}{|c|}{2003} \\
\hline & Mean & SD & Mean & SD \\
\hline Value added per employee at factor costs (in thousands of EUR) & 64.69 & 42.20 & 69.33 & 49.33 \\
\hline Share of workers $<30$ years & 25.73 & 14.3 & 21.94 & 12.92 \\
\hline Share of workers between 30 and 49 years & 60.23 & 13.4 & 61.42 & 12.87 \\
\hline Share of workers $>=50$ years & 14.03 & 8.9 & 16.64 & 10.51 \\
\hline Mean age (years) & 37.37 & 3.63 & 38.49 & 3.53 \\
\hline Standard deviation of age (years) & 9.45 & 1.54 & 9.54 & 1.51 \\
\hline Mean gross hourly wage per employee ${ }^{1}$ (in EUR) & 12.99 & 3.68 & 14.64 & 3.81 \\
\hline Standard deviation of gross hourly wage per employee ${ }^{2}$ (in EUR) & 3.90 & 3.18 & 4.46 & 3.12 \\
\hline Mean tenure (years) & 10.81 & 4.60 & 9.67 & 4.89 \\
\hline Female (percentage) & 27.90 & 25.10 & 29.75 & 29.84 \\
\hline Mean schooling (years) & 11.22 & 1.82 & 11.38 & 1.93 \\
\hline Standard deviation of schooling (years) & 2.03 & 0.81 & 1.88 & 0.82 \\
\hline Blue-collar workers & 45.90 & 34.44 & 51.88 & 35.76 \\
\hline Part-time workers (percentage) & 12.27 & 24.12 & 13.46 & 17.96 \\
\hline Size of the firm (number of workers) & 353.35 & 594.53 & 266.49 & 363.46 \\
\hline \multicolumn{5}{|l|}{ Region } \\
\hline Brussels & 15.87 & & 15.95 & \\
\hline Wallonia & 19.80 & & 20.55 & \\
\hline Flanders & 64.33 & & 63.50 & \\
\hline \multicolumn{5}{|l|}{ Level of wage bargaining: } \\
\hline CA only at national and/or sectoral level ${ }^{2}$ & 45.59 & & 63.77 & \\
\hline CA at the company level ${ }^{2}$ & 45.67 & & 36.23 & \\
\hline Other & 8.74 & & 0 & \\
\hline \multicolumn{5}{|l|}{ Type of financial control } \\
\hline Fully state owned firm & 0.09 & & 0.15 & \\
\hline Mainly state owned firm (>50\%) & 1.90 & & 0.98 & \\
\hline Privately owned firm & 91.61 & & 96.45 & \\
\hline Other & 6.40 & & 2.42 & \\
\hline \multicolumn{5}{|l|}{ Sector } \\
\hline Mining and quarrying (C) & 0.44 & & 0.37 & \\
\hline Manufacturing (D) & 52.43 & & 46.66 & \\
\hline Electricity, gas and water supply (E) & 0.86 & & 0 & \\
\hline Construction (F) & 3.75 & & 8.61 & \\
\hline Wholesale and retail trade; repair of motor vehicles (G) & 21.95 & & 16.64 & \\
\hline Hotels and restaurants $(\mathrm{H})$ & 1.23 & & 2.13 & \\
\hline Transport, storage and communication (I) & 5.86 & & 8.46 & \\
\hline Financial activities $(\mathrm{J})$ & 0 & & 0.97 & \\
\hline Real estate, renting and business activities (K) & 13.48 & & 16.17 & \\
\hline Average number of observations per firm & 34.73 & & 25.05 & \\
\hline Number of firms & 691 & & 1,204 & \\
\hline
\end{tabular}

Number of firms

${ }^{+}$The descriptive statistics refer to the weighted sample.

${ }^{1}$ Individual gross hourly wages include overtime paid, premiums for shift work, night work and/or weekend work.

${ }^{2}$ CA stands for collective labour agreement. 
Table 2: OLS estimates of age structure effects on firm productivity

\begin{tabular}{lccc|ccc}
\hline & \multicolumn{3}{c|}{$\mathbf{1 9 9 5}$} & \multicolumn{3}{c}{$\mathbf{2 0 0 3}$} \\
\hline & $(1)$ & $(2)$ & $(3)$ & $(4)$ & $(5)$ & $(6)$ \\
\hline Log share $<30$ & 0.052 & $0.243^{* *}$ & $0.211^{* *}$ & 0.056 & $0.141^{* *}$ & $0.137^{* *}$ \\
& $(0.122)$ & $(0.055)$ & $(0.045)$ & $(0.050)$ & $(0.038)$ & $(0.037)$ \\
Log share 30-49 & $0.749^{*}$ & $0.536^{* *}$ & $0.415^{* *}$ & $0.381^{* *}$ & $0.252^{*}$ & $0.205^{*}$ \\
& $(0.382)$ & $(0.168)$ & $(0.124)$ & $(0.157)$ & $(0.123)$ & $(0.102)$ \\
Log share 50+ & 0.055 & 0.029 & 0.001 & $0.118^{* *}$ & $0.059^{\circ}$ & $0.053^{\circ}$ \\
& $(0.092)$ & $(0.036)$ & $(0.030)$ & $(0.047)$ & $(0.036)$ & $(0.030)$ \\
\hline Workforce characteristics $^{1}$ & No & Yes & Yes & No & Yes & Yes \\
Firm characteristics & No & No & Yes & No & No & Yes \\
\hline F-stat & $5.02^{* *}$ & $90.72^{* *}$ & $55.95^{* *}$ & $3.13^{* *}$ & $81.62^{* *}$ & $51.34^{* *}$ \\
Adj. R & 0.10 & 0.65 & 0.68 & 0.02 & 0.46 & 0.51 \\
Number of observations & 691 & 691 & 691 & 1,204 & 1,204 & 1,204 \\
\hline
\end{tabular}

Notes: The dependent variable is the ln of value added per capita. Regressions have been estimated by OLS with White (1980) heteroscedasticity-consistent standard errors. Robust standard errors are between brackets.

$* * / * / 0$ : indicate significance at the 1,5 and $10 \%$ level, respectively.

${ }^{1}$ Mean and standard deviation of the number of years of schooling, mean and standard deviation of gross hourly wages, share of blue-collar workers, share of women, percentage of part-time workers.

${ }^{2}$ Sectoral affiliation at the NACE one digit level (seven dummies), size (in level and square), level of collective wage agreement (two dummies), regional affiliation (two dummies), type of economic and financial control (three dummies). 
Table 3: Overall effects of changes in age shares on firm productivity

\begin{tabular}{llll}
\hline A 10\% increase of: & $\begin{array}{l}\text { combined with a } \\
\text { corresponding } \\
\text { decrease of: }\end{array}$ & \multicolumn{2}{l}{$\begin{array}{l}\text { changes firm } \\
\text { productivity by: }\end{array}$} \\
\cline { 2 - 3 } & Middle-aged & $+0.4 \%$ & $+0.6 \%$ \\
\cline { 2 - 3 } Young (<30 years) & Old & $+2.1 \%$ & $+0.7 \%$ \\
& Young & $-4.6 \%$ & $-1.8 \%$ \\
\hline \multirow{2}{*}{ Middle-aged (30-49 years) } & Old & $+4.0 \%$ & $+0.1 \%$ \\
& Young & $-1.1 \%$ & $-0.5 \%$
\end{tabular}

Old (50 years or more)

Middle-aged $\quad-0.9 \% \quad-0.1 \%$

Notes: These effects are based on estimates from columns (3) and (6) of Table 2 and on mean values of age share variables of Table 1. 
Table 4: Means of main variables in ICT and non-ICT sectors ${ }^{+}$

\begin{tabular}{lcccc}
\hline & \multicolumn{2}{c}{$\mathbf{1 9 9 5}$} & \multicolumn{2}{c}{$\mathbf{2 0 0 3}$} \\
\hline & ICT & Non-ICT & ICT & Non-ICT \\
\hline Value added per employee at factor costs (in thousands of & 59.7 & 69.5 & 67.4 & 70.9 \\
EUR) & 26.6 & 24.8 & 23.0 & 21.1 \\
Share of workers < 30 years & 59.6 & 60.9 & 60.9 & 61.8 \\
Share of workers between 30 and 49 years & 13.8 & 14.3 & 16.1 & 17.1 \\
Share of workers >= 50 years & 37.1 & 37.6 & 38.2 & 38.7 \\
Mean age (years) & 9.5 & 9.4 & 9.5 & 9.5 \\
Standard deviation of age & 12.9 & 13.1 & 15.0 & 14.3 \\
Mean gross hourly wage per employee (in EUR) & 4.1 & 3.7 & 4.9 & 4.0 \\
Standard deviation of gross hourly & 38.4 & 17.6 & 40.8 & 20.7 \\
wage per employee & 11.6 & 10.8 & 11.9 & 10.9 \\
Female (percentage) & 1.9 & 2.2 & 1.8 & 1.9 \\
Mean schooling (years) & 36.4 & 55.2 & 34.5 & 66.1 \\
Standard deviation of schooling & 19.0 & 5.7 & 19.01 & 8.9 \\
Blue-collar workers (percentage) & 280.7 & 424.4 & 284.1 & 252.2 \\
Part-time workers (percentage) & & & & \\
Size of the firm (number of workers) & 0 & 0.8 & 0 & 0.6 \\
Sector & 27.5 & 76.8 & 26.6 & 63.0 \\
$\quad$ Mining and quarrying (C) & 1.7 & 0 & 0 & 0 \\
$\quad$ Manufacturing (D) & 0 & 7.4 & 0 & 15.6 \\
Electricity, gas and water supply (E) & 41.5 & 3.1 & 34.1 & 2.4 \\
Construction (F) & 0 & 2.4 & 0 & 3.9 \\
Wholesale and retail trade (G) & 2.1 & 9.5 & 1.8 & 13.9 \\
Hotels and restaurants (H) & 0 & 0 & 2.1 & 0 \\
Transport, storage and communication (I) & 27.2 & 0 & 35.4 & 0.6 \\
Financial activities (J) & 295 & 396 & 499 & 705 \\
\hline Real estate, renting and business activities (K) & & & & \\
\hline Number of firms & & &
\end{tabular}

${ }^{+}$The descriptive statistics refer to the weighted sample. 
Table 5: Age structure effects on firm productivity: ICT vs. non-ICT sectors

\begin{tabular}{|c|c|c|c|c|}
\hline & \multicolumn{2}{|c|}{1995} & \multicolumn{2}{|c|}{2003} \\
\hline & ICT & Non-ICT & ICT & Non-ICT \\
\hline & $(1)$ & (2) & (3) & (4) \\
\hline Log share $<30$ & $0.23^{* *}$ & $0.35 * *$ & $0.19 * *$ & $0.09 *$ \\
\hline & $(0.06)$ & $(0.07)$ & $(0.06)$ & $(0.04)$ \\
\hline Log share $30-49$ & $0.25^{\circ}$ & $0.81^{* *}$ & $0.28^{\circ}$ & $0.20^{\circ}$ \\
\hline & $(0.14)$ & $(0.19)$ & $(0.17)$ & $(0.12)$ \\
\hline Log share $50+$ & -0.02 & $0.11 *$ & 0.05 & $0.07^{\circ}$ \\
\hline & $(0.03)$ & $(0.05)$ & $(0.05)$ & $(0.04)$ \\
\hline Workforce characteristics $^{1}$ & Yes & Yes & Yes & Yes \\
\hline Firm characteristics ${ }^{2}$ & Yes & Yes & Yes & Yes \\
\hline F-stat & $46.95 * *$ & $14.7 * *$ & $26.9 * *$ & $35.3 * *$ \\
\hline Adj. $\mathrm{R}^{2}$ & 0.76 & 0.54 & 0.54 & 0.47 \\
\hline Number of observations & 295 & 396 & 499 & 705 \\
\hline
\end{tabular}

Notes: The dependent variable is the ln of value added per capita. Regressions have been estimated by OLS with White (1980) heteroscedasticity-consistent standard errors. Robust standard errors are between brackets.

$* * / * / \circ$ : indicate significance at the 1,5 and $10 \%$ level, respectively.

${ }^{1}$ Mean and standard deviation of the number of years of schooling, mean and standard deviation of gross hourly wages, share of blue-collar workers, share of women, percentage of part-time workers.

${ }^{2}$ Sectoral affiliation at the NACE one digit level (seven dummies), size (in level and square), level of collective wage agreement (two dummies), regional affiliation (two dummies), type of economic and financial control (three dummies). 
Table 6: Overall effects of changes in age shares on firm productivity in ICT and non-

\begin{tabular}{|c|c|c|c|c|c|}
\hline \multirow[t]{3}{*}{ A $10 \%$ increase of: } & \multirow{3}{*}{$\begin{array}{l}\text { combined with a } \\
\text { corresponding } \\
\text { decrease of: }\end{array}$} & \multicolumn{4}{|c|}{ changes firm productivity by: } \\
\hline & & & 95 & & 03 \\
\hline & & ICT & Non-ICT & ICT & Non-ICT \\
\hline \multirow{2}{*}{ Young (<30 years) } & Middle-aged & $+1.2 \%$ & $+0.2 \%$ & $+0.8 \%$ & $+0.2 \%$ \\
\hline & Old & $+2.6 \%$ & $+1.5 \%$ & $+1.9 \%$ & $+0.1 \%$ \\
\hline \multirow{2}{*}{ Middle-aged (30-49 years) } & Young & $-3.1 \%$ & $-0.6 \%$ & $-2.2 \%$ & $-0.6 \%$ \\
\hline & Old & $+2.5 \%$ & $+3.3 \%$ & $+2.8 \%$ & $-0.5 \%$ \\
\hline \multirow{2}{*}{ Old (50 years or more) } & Young & $-1.2 \%$ & $-0.9 \%$ & $-1.3 \%$ & $-0.1 \%$ \\
\hline & Middle-aged & $-0.6 \%$ & $-0.6 \%$ & $-0.7 \%$ & $+0.1 \%$ \\
\hline
\end{tabular}

Notes: These effects are based on estimates from Table 5 and on mean values of age share variables of Table 4. 
Table 7: Age structure effects on firm productivity correcting for simultaneity

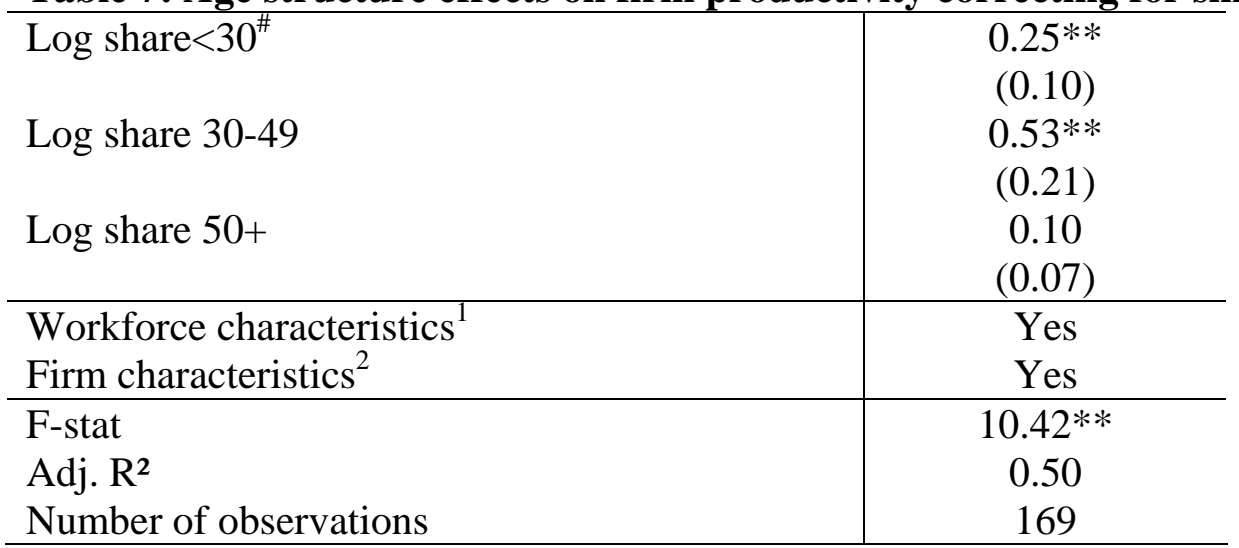

Notes: The dependent variable is the ln of value added per capita in 2003. Regression has been estimated by OLS with White (1980) heteroscedasticity-consistent standard errors. Robust standard errors are between brackets.

\# : values of the log of age shares per firm in 1995.

$* * / * /{ }^{\circ}$ : indicate significance at the 1,5 and $10 \%$ level, respectively.

${ }^{1}$ Mean and standard deviation of the number of years of schooling, mean and standard deviation of gross hourly wages, share of blue-collar workers, share of women, percentage of part-time workers.

${ }^{2}$ Sectoral affiliation at the NACE one digit level (seven dummies), size (in level and square), level of collective wage agreement (two dummies), regional affiliation (two dummies), type of economic and financial control (three dummies). 
Table 8: Overall effects of changes in age shares on firm performance correcting for simultaneity

\begin{tabular}{llc}
\hline A 10\% increase of: & $\begin{array}{l}\text { combined with a } \\
\text { corresponding } \\
\text { decrease of: }\end{array}$ & $\begin{array}{l}\text { changes firm } \\
\text { productivity } \\
\text { by: }\end{array}$ \\
\hline Young (<30 years) & Middle-aged & $+0.2 \%$ \\
& Old & $+2.5 \%$ \\
Middle-aged (30-49 years) & Young & $-0.6 \%$ \\
& Old & $+5.3 \%$ \\
\hline Old (50 years or more) & Young & $-1.4 \%$ \\
& Middle-aged & $-1.2 \%$
\end{tabular}

\footnotetext{
Notes: These effects are based on estimates from Table 7 and on mean values of age share variables in 1995 (Appendix I).
} 


\section{Appendix I}

Means and standard deviations of selected variables (Panel)

\begin{tabular}{|c|c|c|c|c|}
\hline \multirow{2}{*}{$\begin{array}{l}\text { Year } \\
\text { Variables } \\
\end{array}$} & \multicolumn{2}{|c|}{1995} & \multicolumn{2}{|c|}{2003} \\
\hline & Mean & SD & Mean & SD \\
\hline Value added per employee at factor costs (in thousands of EUR) & 58.8 & 33.1 & 73.8 & 41.9 \\
\hline Share of workers $<30$ years & 26.8 & 16.1 & 19.1 & 11.8 \\
\hline Share of workers between 30 and 49 years & 59.2 & 15.1 & 61.4 & 13.7 \\
\hline Share of workers $>=50$ years & 13.9 & 9.5 & 19.4 & 11.1 \\
\hline Mean age (years) & 37.3 & 4.3 & 39.6 & 3.1 \\
\hline Standard deviation of age (years) & 9.5 & 1.5 & 9.7 & 1.6 \\
\hline Mean gross hourly wage per employee ${ }^{1}$ (in EUR) & 12.3 & 3.3 & 15.4 & 4.2 \\
\hline Standard deviation of gross hourly wage per employee ${ }^{2}$ (in EUR) & 3.7 & 2.4 & 4.9 & 3.2 \\
\hline Mean tenure (years) & 11.0 & 4.8 & 11.4 & 4.3 \\
\hline Female (percentage) & 23.2 & 21.1 & 24.9 & 20.3 \\
\hline Mean schooling (years) & 11.3 & 1.7 & 11.38 & 1.93 \\
\hline Standard deviation of schooling (years) & 2.1 & 0.7 & 1.88 & 0.82 \\
\hline Blue-collar workers & 44.5 & 32.0 & 53.5 & 34.1 \\
\hline Part-time workers (percentage) & 7.9 & 20.5 & 10.4 & 12.1 \\
\hline Size of the firm (number of workers) & 294.7 & 280.7 & 262.7 & 164.6 \\
\hline \multicolumn{5}{|l|}{ Region } \\
\hline Brussels & 14.7 & & 14.4 & \\
\hline Wallonia & 13.5 & & 16.1 & \\
\hline Flanders & 71.8 & & 69.5 & \\
\hline \multicolumn{5}{|l|}{ Level of wage bargaining: } \\
\hline CA only at national and/or sectoral level ${ }^{2}$ & 47.3 & & 59.8 & \\
\hline $\mathrm{CA}_{\text {at }}$ the company level ${ }^{2}$ & 42.9 & & 40.2 & \\
\hline Other & 9.8 & & 0 & \\
\hline \multicolumn{5}{|l|}{ Sector } \\
\hline Mining and quarrying (C) & 0 & & 0 & \\
\hline Manufacturing (D) & 63.3 & & 63.3 & \\
\hline Electricity, gas and water supply (E) & 0 & & 0 & \\
\hline Construction (F) & 9.9 & & 9.9 & \\
\hline Wholesale and retail trade; repair of motor vehicles (G) & 12.4 & & 12.4 & \\
\hline Hotels and restaurants $(\mathrm{H})$ & 1.2 & & 1.2 & \\
\hline Transport, storage and communication (I) & 3.8 & & 3.8 & \\
\hline Financial activities $(\mathrm{J})$ & 0 & & 0 & \\
\hline Real estate, renting and business activities (K) & 9.4 & & 9.4 & \\
\hline Number of observations per firm & 24.8 & & 25.3 & \\
\hline
\end{tabular}

${ }^{1}$ Individual gross hourly wages include overtime paid, premiums for shift work, night work and/or weekend work.

${ }^{2}$ CA stands for collective labour agreement. 